УДК 539.3

\title{
Forced liquid vibrations in prismatic tanks under vertical and horizontal loads
}

\author{
D.V. Kriutchenko \\ Институт проблем машиностроения им. А.Н.Подгорного НАНУ, Украина \\ wollydenis@gmail.com
}

The method of studying forced vibrations of a liquid in rigid prismatic tanks partially filled with a liquid is offered. It is supposed that the liquid is an ideal and incompressible one, and its motion, caused by the action of external influences, is irrotational. For those assumptions there is velocity potential that satisfies the Laplace equation. The boundary value problem for this potential is formulated. On the wetted surfaces of the tank the non-penetration conditions have been chosen. On the free surface of the liquid, the kinematic and static conditions have been specified. The static condition is the equality of pressure on the free surface to atmospheric one. The liquid pressure is determined from the Cauchy-Lagrange integral. To formulate the kinematic condition an additional unspecified function describing the motion of the free surface is introduced. The kinematic condition is the equality of the velocity of the liquid described by the velocity potential, and the velocity of the free surface itself. The modes of free vibrations are used as a system of basic functions to solve the problems of forced fluid vibrations in reservoirs. Unspecified functions are presented as series of the basic functions. The coefficients of these series are generalized coordinates. Periodic excitation forces acting in the vertical and horizontal directions have been considered. The vertical excitation examination leads to appearance of additional acceleration. Therefore we obtain a system of unbounded differential equations of the Mathieu type. This allows us to investigate the phenomena of parametric resonance. The effect of parametrical resonance is considered when the vertical excitation frequency is equal to double own frequency of liquid vibrations. Dependences of change in the level of free surface via time under both separate and mutual action of horizontal and vertical forces have been obtained. The phase portraits of a dynamic system with indication of resonances are presented. The method allows us to carry out the adjustment of undesired excitation frequencies at the reservoir design stage in order to prevent the loss of stability.

Key words: prismatic reservoirs, ideal incompressible fluid, vertical and horizontal excitations, Mathieu's equation, phase portraits

Запропоновано метод дослідження вимушених коливань рідини в жорстких призматичних резервуарах, частково заповнених рідиною. Вважається, що рідина є ідеальною і нестисливою, а ії рух, викликаний дією зовнішніх впливів, $\epsilon$ безвихровим. У цих припущеннях існує потенціал швидкості, який задовольняє рівнянню Лапласа. Сформульована крайова задача для цього потенціалу. На змочених поверхнях резервуара мають виконуватись умови непротікання. На вільній поверхні рідини задаються кінематичні та статичні умови. Статична умова полягає в рівності тиску на вільній поверхні до атмосферного. Тиск рідини визначається інтегралом Коші-Лагранжа. Для формулювання кінематичної умови вводиться додаткова невідома функція, яка описує рух вільної поверхні. Кінематична умова - це рівність швидкості рідини, яка описується потенціалом швидкості, і швидкістю самої вільної поверхні. Ці форми вільних коливань використовуються як система них функцій при вирішенні проблем вимушених коливань рідини у водоймах. Невідомі функції представлені у вигляді ряду основних функцій. Коефіцієнти цих рядів є узагальненими координатами. Розглянуто періодичні сили збудження, що діють у вертикальному та горизонтальному напрямках. Якщо вивчається вертикальне збудження, це призводить до появи додаткового прискорення. Тут ми отримуємо систему диференціальних рівнянь типу Матьє. Це дозволяє дослідити явища параметричного резонансу. Вплив параметричного резонансу вважається тоді, коли частота вертикального збудження дорівнює подвійній власній частоті коливань рідини. Отримані залежності зміни рівня вільної поверхні від часу внаслідок взаємної дії горизонтальних та вертикальних сил. Подані фазові портрети динамічної системи із зазначенням резонансів. Метод дозволяє здійснити регулювання небажаних частот збудження на етапі проектування при виробництві резервуара 3 метою запобігання втрати стійкості.

Ключові слова: призматичні резервуари, ідеальна нестислива рідина, вертикальні та горизонтальні збудження, рівняння Матьє, фазові портрети

Предложен метод исследования вынужденных колебаний жидкости в жестких призматических резервуарах, частично заполненных жидкостью. Предполагается, что жидкость является идеальной и несжимаемой, а ее движение, вызванное действием внешних воздействий, является безвихревым. В этих предположениях существует потенциал скорости, который удовлетворяет уравнению Лапласа. Сформулированная краевая задача для этого потенциала. На смоченных поверхностях резервуара существуют условия непротекания. На свободной поверхности жидкости задаются кинематические и статические условия. Статические условия состоят в равенстве давления на свободной поверхности к атмосферному. Давление жидкости определяется интегралом Коши-Лагранжа. Для формулировки кинематического условия вводится дополнительная неизвестная функция, которая описывает движение свободной поверхности. Кинематическое условие - это равенство скорости жидкости, которая описывается потенциалом скорости, и скорости самой свободной поверхности. Формы свободных колебаний используются как система базисных функций при решении проблем вынужденных колебаний жидкости в резервуарах. Неизвестные функции представлены в виде рядов по базисных функций. Коэффициенты этих рядов являются обобщенными координатами. Рассмотрены периодические силы возбуждения, действующие в вертикальном и горизонтальном направлениях. Если изучается вертикальное возбуждение, это приводит к появлению дополнительного ускорения. Здесь мы получаем систему дифференциальных уравнений типа Матье. Это позволяет исследовать явления параметрического резонанса. Влияние параметрического резонанса возникает тогда, когда частота вертикального возбуждения равна двойной 
собственной частоте колебаний жидкости. Полученные зависимости изменения уровня свободной поверхности от времени при взаимном действии горизонтальных и вертикальных сил. Представлены фазовые портреты динамической системы с указанием резонансов. Метод позволяет осуществить отстройку от нежелательных частот возбуждения на этапе проектирования при изготовлении резервуаров с целью предотвращения потери устойчивости.

Ключевые слова: призматические резервуары, идеальная несжимаемая жидкость, вертикальные и горизонтальные нагрузки, уравнения Матье, фазовые портреты

\section{Formulation of the problem and its relevance}

Containers and reservoirs for the storage and transportation of different liquids are widely used in aerospace, chemical, oil and gas industry, power engineering, sea transport. These reservoirs and fuel tanks are usually filled with oil or other dangerously explosive, flammable or toxic substances. Fluid motion in liquid storage tanks due to intensive external loadings can be very complicated and violent. Therefore, studying the dynamic behavior of fluid in tanks is an urgent task. During past decades the significant progress in experimental technique and numerical methods based on using the computational fluid dynamics approach has been achieved. But these techniques are very expensive and timeconsuming. Therefore the linear wave models based on the potential flow assumptions are suitable as the first approximation at designing the liquid storage reservoirs. The most important problems are associated with fluid motion in reservoirs caused by external loadings, especially applied suddenly.

The methods for solving fluid oscillation problems in rigid prismatic tanks under simultaneous action of horizontal and vertical excitations are proposed in this paper.

\section{Analysis of recent research and publications}

Sloshing is a phenomenon associated with the intense movement of fluid in partially filled tanks [1]. This phenomenon can lead to negative effects caused by suddenly applied loads (earthquakes, aircraft crashes, etc.). Most studies are devoted to the analysis of free liquid vibrations [2-4] or excitation forces acting only in the horizontal direction [5-7]. Liquid vibrations in fluid-filled prismatic tanks under action of horizontal loading have been studied in [8]. The liquid motion under action of harmonic force has been considered. Kim has carried out the numerical simulation of sloshing to predict impact loads and provided comparison of various numerical techniques in [9]. The effects of sloshing have been considered for viscid liquids in [10]. The authors of [11] have used the coupled finite and boundary elements method for sloshing in 3D tanks of different configurations. Parametric instability of liquid free surface in different fluid-filled reservoirs caused by vertical excitations has been the subject of extensive research in many scientific areas since Faraday's first works [12].

\section{The aim of the study}

The aim of the study is to create the methodology for estimating the amplitude of the liquid free surface vibrations in prismatic tanks under action of various external influences.

\section{Outline of the main research material}

This paper deals with the problems of free and forced oscillations of liquids in rigid prismatic tanks. It is assumed that the external load can act either horizontally or vertically. The scheme of the tank is shown in Fig. 1.

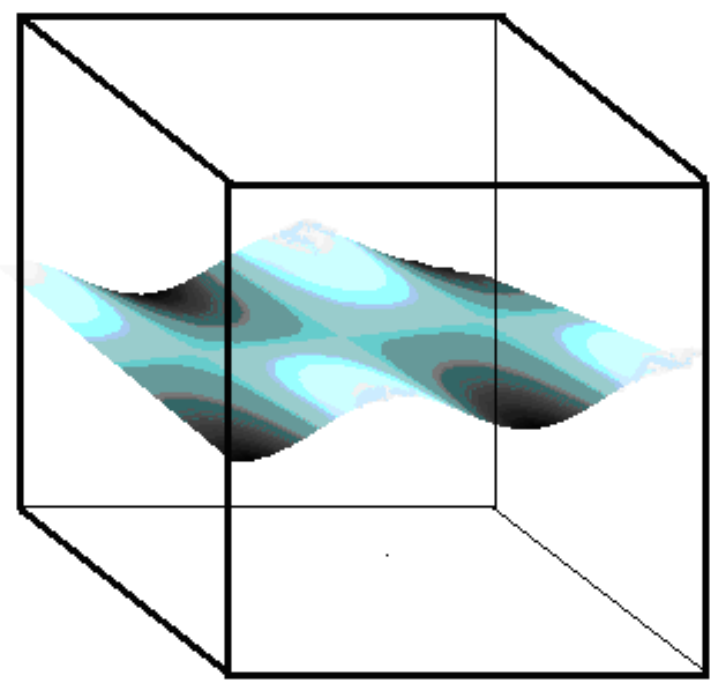

Figure 1. Sketch of fluid-filled prismatic tank 
We suppose that the fluid is inviscid, incompressible, and its motion is irrotational. Under these conditions, there exists a potential of velocities $\varphi(x, y, z, t)$, such that

$$
V_{x}=\frac{\partial \varphi}{\partial x} ; V_{y}=\frac{\partial \varphi}{\partial y} ; V_{z}=\frac{\partial \varphi}{\partial z}
$$

This potential satisfies the Laplace equation. The mixed boundary value problem for this equation is formulated. At the same time, non-penetration conditions are set on the lateral surfaces and the bottoms of the reservoir, and kinematic and dynamic conditions are set on the free surface. The kinematic condition is that the point on the free surface of the fluid in the reservoir at the initial time of motion remains on that surface throughout the whole movement. The dynamic condition characterizes the equilibrium of the atmospheric pressure and the fluid pressure on the free surface. The unknowns are the velocity potential $\varphi$ and function $\zeta$ that describes the level the free surface elevation. The relationship between these two functions is given by the dynamic boundary condition

$$
\frac{\partial \varphi}{\partial t}+g \zeta=0
$$

where $g$ is the gravity acceleration. Let the equation of the free surface at the initial instant of time have the form $\zeta=0$. Designate a moistened shell surface by $S_{1}$, and a free surface by $S_{0}$.

The boundary wall and bottom conditions are

$$
\left.\frac{\partial \varphi}{\partial \mathbf{n}}\right|_{\mathbf{S}_{1}}=0
$$

Supposing that the Cartesian coordinate system $0 x y z$ is connected with reservoirs under consideration, the liquid free surface $S_{0}$ coincides with the plane $z=0$ at the state of rest. Let us assume that the liquidfilled shell is under vertical and horisontal driven forces with accelerations $\mathbf{a}_{x}$ and $\mathbf{a}_{z}$

$$
\mathbf{a}_{x}=a_{x}(t) \mathbf{i}, \quad \mathbf{a}_{\mathrm{z}}=a_{\mathrm{z}}(t) \mathbf{k},
$$

where factors $a_{x}(t), a_{z}(t)$ depend on time $t$ only. $\mathbf{i}$ and $\mathbf{k}$ are the unit vectors along $\mathrm{O} x$ and $\mathrm{O} z$.

Firstly we obtain a relation between the velocity potential, the liquid pressure, and accelerations due to driving forces and gravity. We have

$$
\mathbf{a}_{x}=\nabla\left[x \cdot a_{x}(t)\right], \mathbf{a}_{z}=\nabla\left[z \cdot a_{z}(t)\right], \mathbf{g}=-\nabla(\rho g z),
$$

where $x, z$ are coordinates of a point in the liquid.

Motion equations for the ideal incompressible liquid can be presented in the vector form as follows [18]:

$$
\mathbf{w}+\nabla\left(x a_{x}(t)\right)+\nabla\left(z a_{z}(t)\right)+\nabla(g z)=-\frac{\nabla p}{\rho},
$$

where $\mathbf{w}$ is the acceleration of the fluid flow, $\rho$ is the liquid density, and $p$ is the fluid pressure.

Therefore the acceleration of liquid particles under gravitational forces, horizontal, and vertical excitations always has the potential (an analog of the Prandtl's potential). Using equation (4.3) and assuming that the flow is irrotational, Bernoulli equation can be derived in the following form:

$$
p-p_{0}=-\rho\left[\frac{\partial \Phi}{\partial t}+a_{x}(t) x+\left(g+a_{z}(t)\right) z+\frac{1}{2}|\nabla \Phi|^{2}\right],
$$

where $p_{0}$ is the atmospheric pressure. If small oscillations of the liquid are considered then $|\nabla \Phi|^{2}<<1$, and we have the next expression:

$$
p-p_{0}=-\rho\left[\frac{\partial \Phi}{\partial t}+a_{x}(t) x+\left(g+a_{z}(t)\right) z\right]
$$

Thus, for the velocity potential, we have the following boundary value problem:

$$
\nabla^{2} \Phi=0 ;\left.\frac{\partial \Phi}{\partial \mathbf{n}}\right|_{S_{w}}=0 ;\left.\frac{\partial \Phi}{\partial n}\right|_{S_{0}}=\frac{\partial \zeta}{\partial t} ; \quad p-\left.p_{0}\right|_{S_{0}}=0,
$$

where $p-p_{0}$ is defined by formula (4.5), where $z=\zeta(x, y, t)$.

To satisfy the solvability conditions for the boundary value problem (4.6), it is also necessary to add the Neumann condition 


$$
\int_{S_{0}} \frac{\partial \Phi}{\partial \mathbf{n}} d S=0
$$

To solve the problem of forced oscillations we construct a system of basis functions, which are the solutions of the spectral boundary value problem

$$
\nabla^{2} \Phi=0 ;\left.\frac{\partial \Phi}{\partial \mathbf{n}}\right|_{S_{w}}=0,\left.\frac{\partial \Phi}{\partial n}\right|_{S_{0}}=\frac{\partial \zeta}{\partial t} ; \quad p-\left.p_{0}\right|_{S_{0}}=0, \frac{\partial \Phi}{\partial t}+\left.g \zeta\right|_{S_{0}}=0
$$

under additional condition (4.7).

We present the expressions for the first 8 eigenmodes of fluid oscillations obtained in [13]. This is a system of basis functions obtained as a solution to problem (4.6) - (4.7) for studying forced oscillations.

$$
\begin{gathered}
\Psi_{01}(x)=C_{1} \cos (0 \cdot x) \sin \frac{\pi}{2 b} y \Psi_{10}(x)=C_{2} \sin \frac{\pi}{2 a} x \cos (0 \cdot y) \Psi_{11}(x)=C_{3} \sin \frac{\pi}{2 a} x \sin \frac{\pi}{2 b} y \\
\Psi_{20}(x)=C_{5} s \cos \frac{\pi}{a} x \cos (0 y) \\
\Psi_{02}(x)=C_{5} s \cos 0 x \cos \left(\frac{\pi}{b} y\right) \quad \Psi_{21}(x)=C_{6} \cos \frac{\pi}{a} x \sin \frac{\pi}{2 b} y \\
\Psi_{12}(x)=C_{7} \sin \frac{\pi}{2 a} x \cos \frac{\pi}{b} y \quad \Psi_{22}(x)=C_{8} \cos \frac{\pi}{a} x \cos \frac{\pi}{b} y
\end{gathered}
$$

In the Tab. 1 the natural frequencies of fluid oscillations in a prismatic reservoir are shown.

Fig. 1 shows the numerical values of the frequencies $\omega \mathrm{ij}$ and the frequency parameter $\lambda_{i j}$ for a cubeshaped prismatic reservoir with geometric characteristics $a=b=H=1 \mathrm{M}$

Table 1. Natural frequencies of fluid oscillations in a prismatic reservoir

\begin{tabular}{|c|c|c|c|c|}
\hline $\mathrm{n}$ & $\mathrm{i}$ & $\mathrm{j}$ & $\lambda_{\mathrm{ij}}$ & $\omega_{\mathrm{ij}}$ \\
\hline 1 & 0 & 1 & 1.772453851 & 4.051164194 \\
\hline 2 & 1 & 0 & 1.772453851 & 4.051164194 \\
\hline 3 & 1 & 1 & 2.506628275 & 5.710012556 \\
\hline 4 & 0 & 2 & 3.544907703 & 5.892165855 \\
\hline 5 & 2 & 0 & 3.544907703 & 5.892165855 \\
\hline 6 & 2 & 1 & 3.963327298 & 6.233151691 \\
\hline 7 & 1 & 2 & 3.963327298 & 6.233151691 \\
\hline 8 & 2 & 2 & 5.013256550 & 7.012538645 \\
\hline
\end{tabular}

To find the function $\zeta$ we use the following expression for the velocity potential

$$
\Phi=\sum_{n=1}^{M} \dot{c}_{n}(t) \Phi_{n}
$$

where the addiction $n=n(i, j)$ is shown in Tab. 1 , function $\Phi_{n}$ is determined by [13]

$$
\Phi_{n}=\frac{1}{a b} \frac{\cosh \left(\lambda_{i j} z\right)}{\cosh \left(\lambda_{i j} H\right)} \Psi_{i j}(x, y) ; \quad n=n(i, j), \lambda_{i j}=\sqrt{\left(\frac{\pi i}{2 a}\right)^{2}+\left(\frac{\pi j}{2 b}\right)^{2}}
$$

where $\Psi_{i i}$ are found using relation (4.9).

Then, provided that $z=H$, we obtain

$$
\zeta=\sum_{n=1}^{M} c_{k}(t) \frac{\partial \Phi_{k}}{\partial \mathbf{n}}
$$

Orthogonality check gives the following relation: 


$$
\int_{-a-b}^{a} \int_{k}^{b} \Phi_{k}(x, y) \Phi_{l}(x, y) d x d y=a b \delta_{k l}
$$

\section{Forced fluid oscillations in a rigid tank}

Let us suppose that at the initial time, the liquid in the tank is at the state of rest. A combined periodic load is applied to the tank in horizontal and vertical directions.

We compose a system of differential equations of fluid motion based on the boundary condition on the free surface

$$
\frac{\partial \Phi}{\partial t}+a_{x}(t) x+\left(g+a_{z}(t)\right) \zeta=0
$$

where

$$
\begin{aligned}
& \Phi=\sum_{k=1}^{N} \dot{c}_{k}(t) \Phi_{k}(x, y, H), \\
& \zeta=\sum_{k=1}^{N} c_{k}(t) \frac{\partial \Phi_{k}}{\partial z}(x, y, H) .
\end{aligned}
$$

Let us consider equation

$$
\frac{\partial \Phi}{\partial t}+a_{x}(t) x+\left(g+a_{z}(t)\right) \zeta(x, y, t)=0
$$

Substituting equations (5.1) to equation (5.2) we obtain

$$
\sum_{k=1}^{N} \ddot{c}_{k}(t) \Phi_{k}(x, y, H)+a_{x}(t) x+\left(g+a_{z}(t)\right) \sum_{k=1}^{N} c_{k}(t) \frac{\partial \Phi_{k}}{\partial z}(x, y, H)=0
$$

where

$$
\frac{\partial \Phi_{k}}{\partial z}=\frac{\sinh \left(\lambda_{i j} z\right) \lambda_{i j}}{\cosh \left(\lambda_{i j} \mathrm{H}\right)} \psi_{i j}(x, \mathrm{y})
$$

It should be noted that for $z=H$

$$
\Phi_{n}(x, y, H)=\frac{1}{a b} \psi_{i j}(x, y), \quad \frac{\partial \Phi_{n}}{\partial z}=\frac{1}{g} \omega_{n}^{2} \Phi_{n} .
$$

After a dot product of equation (5.3) by $\Phi_{l}(x, y, H)$ we obtain the following system of differential equations of the second order:

$$
a b \ddot{c}_{l}(t)+a_{x}(t)\left(x, \Phi_{l}\right)+\omega_{l}^{2}\left(g+a_{z}(t)\right) a b c_{l}(t)=0, \quad l=1,2, \ldots, N
$$

It should be noted that $\left(x, \Phi_{l}\right)=0$, for every modes except $\mathrm{i}=2$. Therefore considering the following initial data:

$$
c_{i}(0)=0 ; \quad \dot{c}_{i}(0)=0 ; \quad i=1,3 \ldots \quad c_{2}(0)=0 ; \quad \dot{c}_{2}(0)=0.05 .
$$

we obtain:

$$
a b \ddot{c}_{2}(t)+a_{1} \cos \Omega_{1} t\left(x, \Phi_{2}\right)+\omega_{2}^{2}\left(g+a_{2} \cos \Omega_{2} t\right) c_{2}(t)=0
$$

\section{Numerical results}

Let us consider liquid vibration in prismatic tank with following parameters: $a=b=1 \mathrm{~m}$. $\omega_{2}=4.05 \mathrm{~Hz}$ at different $a_{1}, a_{2}, \Omega_{1}, \Omega_{2}$. The results are shown in Fig. 2-6. In Fig. 2 the phase portraits for separate and mutual actions of horizontal and vertical excitations are demonstrated: 


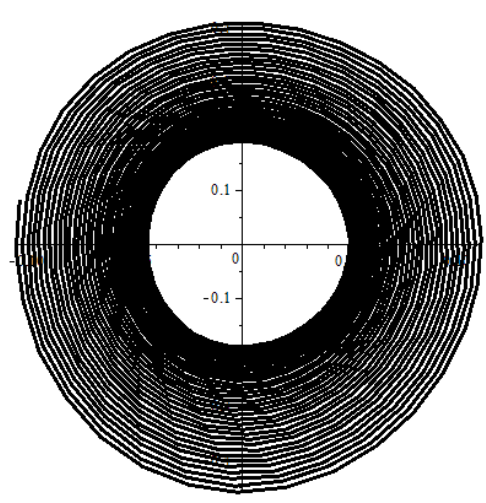

a

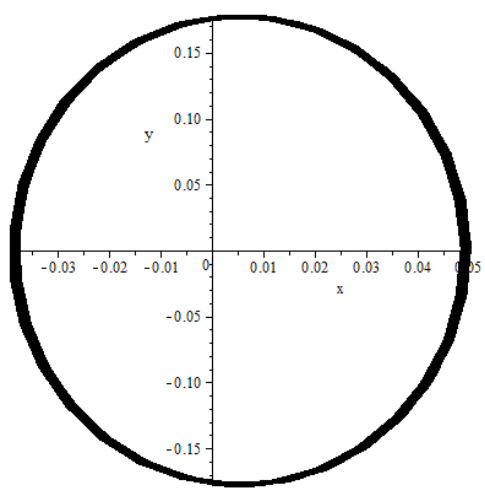

b

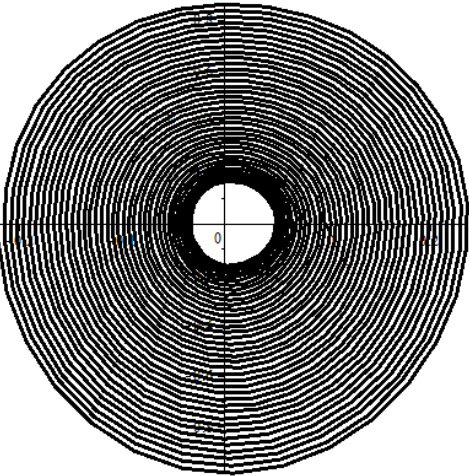

c

Figure 2. Phase portraits for $\Omega_{2}=4.05 \mathrm{~Hz}, a_{2}=1.81$ during $60 \mathrm{sec}$.

Fig. 2(a) corresponds to $a_{1}=0, a_{2}=1.81$ for vertical excitation only. Fig. 2(b) corresponds to $a_{1}=0.1, \quad a_{2}=0, \quad \Omega_{1}=0.01 \mathrm{~Hz}$ for horizontal excitation only. Fig. 2(c) corresponds to mutual action of horizontal and vertical excitations with abovementioned parameters. The processes of vibrations shown in Fig. 2(a) and 2(b) are unstable, but the loosing of stability due mutual action of horizontal and vertical loads begins earlier.

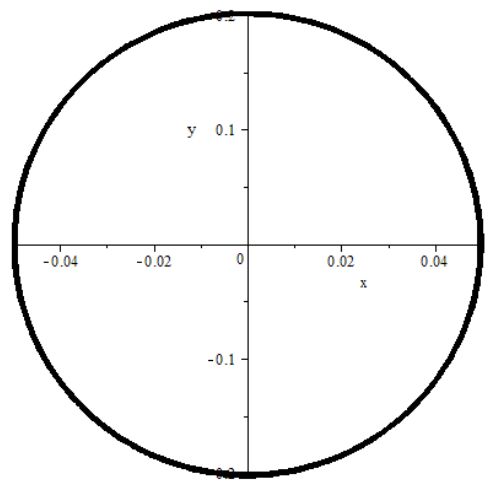

a

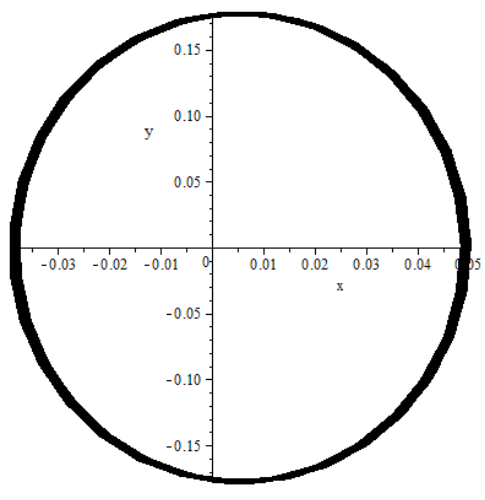

b

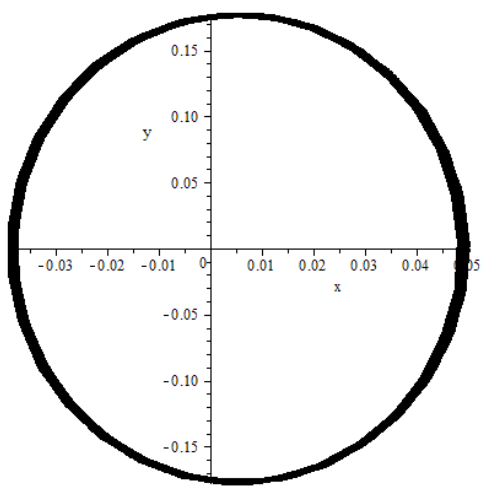

$\mathrm{c}$

Figure 3. Phase portraits for $\Omega_{2}=4.05 \mathrm{~Hz}, a_{2}=0.1$ during $60 \mathrm{sec}$.

Fig. 3(a) corresponds to $a_{1}=0, a_{2}=0.1$ for vertical excitation only. Fig. 3(b) corresponds to $a_{1}=0.1, \quad a_{2}=0, \quad \Omega_{1}=0.01 \mathrm{~Hz}$ for horizontal excitation only. Fig. 3(c) corresponds to mutual action of horizontal and vertical excitations with abovementioned parameters. In this case the stability of vibration process can be observed.

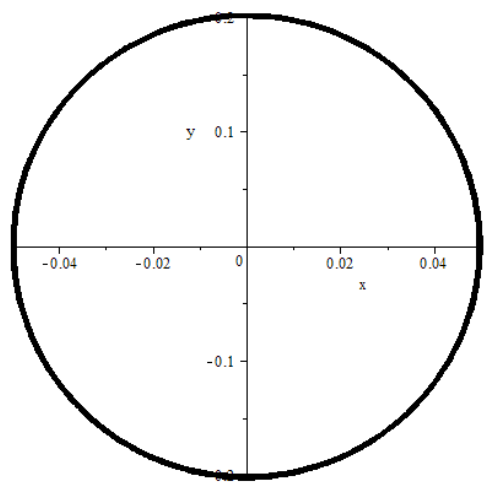

a

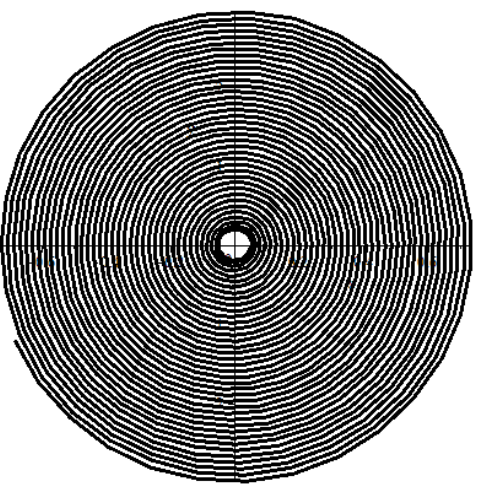

$\mathrm{b}$

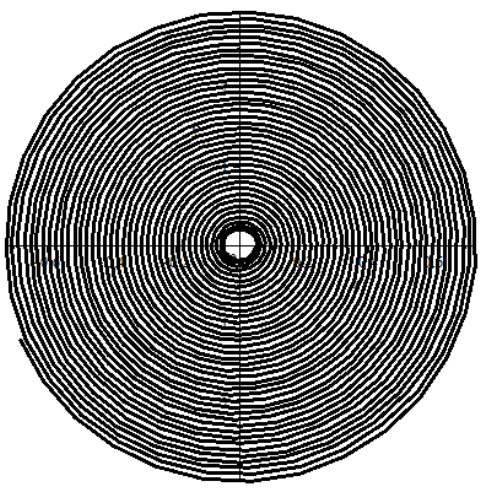

$\mathrm{c}$

Figure 4. Phase portraits for $\Omega_{1}=4.05, \Omega_{2}=4.05 \mathrm{~Hz}, a_{2}=0.1$ during 60 sec. 
Fig. 4(a) corresponds to $a_{1}=0, a_{2}=0.1$ for vertical excitation only. Fig. 4(b) corresponds to $a_{1}=0.1, \quad a_{2}=0, \quad \Omega_{1}=4.05 \mathrm{~Hz}$ for horizontal excitation only. Fig. 4(c) corresponds to mutual action of horizontal and vertical excitations with abovementioned parameters. In this case the vibration process is unstable, and vertical excitation is not essential.

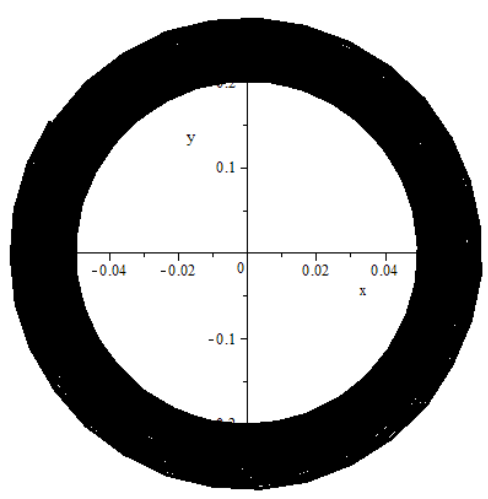

a

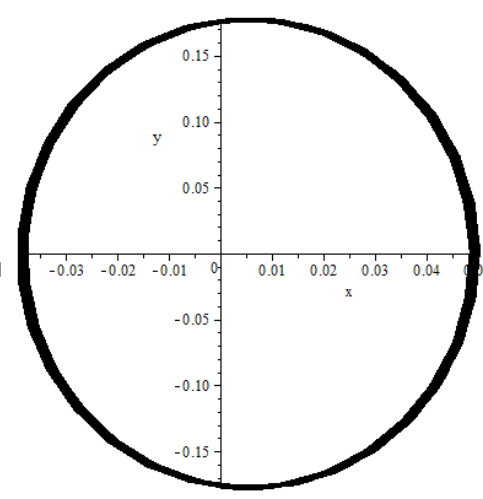

b

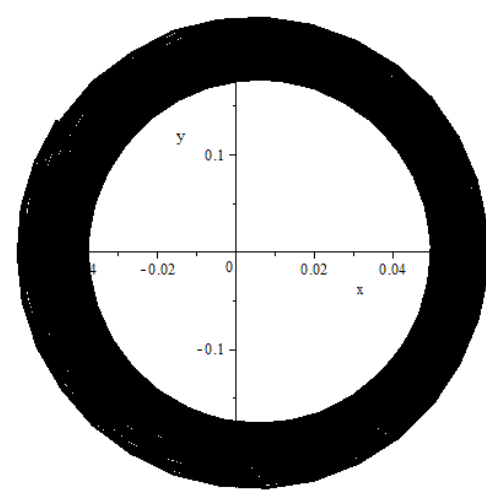

$\mathrm{C}$

Figure 5. Phase portraits for $\Omega_{1}=0.012, \Omega_{2}=8.1 \mathrm{~Hz}, a_{2}=0.1$ during $60 \mathrm{sec}$.

Fig. 5(a) corresponds to $a_{1}=0, a_{2}=0.1$ for vertical excitation only. Fig. 5(b) corresponds to $a_{1}=0.1, \quad a_{2}=0, \quad \Omega_{1}=0.012 \mathrm{~Hz}$ for horizontal excitation only. Fig. 5(c) corresponds to mutual action of horizontal and vertical excitations with abovementioned parameters. In this case the vibration process is unstable, but horizontal excitation is not essential.

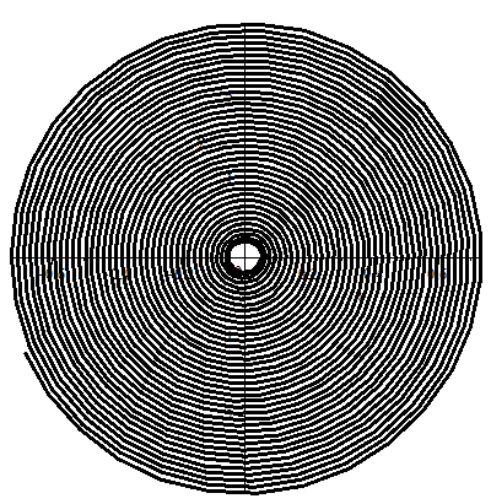

a

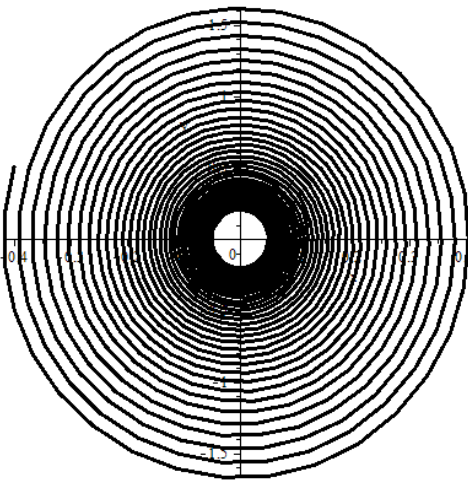

b

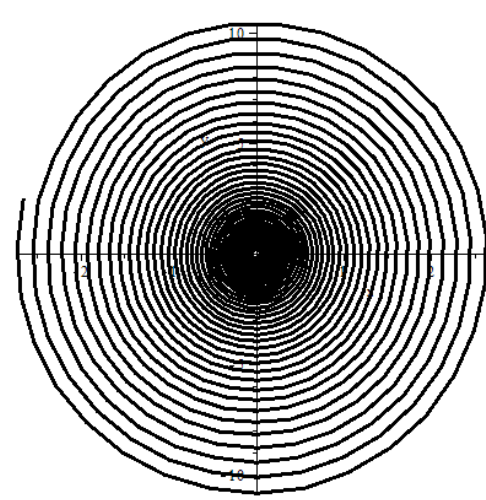

$\mathrm{c}$

Figure 6. Phase portraits for $\Omega_{1}=4.05, \Omega_{2}=8.1 \mathrm{~Hz}, a_{2}=0.1$ during $60 \mathrm{sec}$.

Fig. 6(a) corresponds to $a_{1}=0, a_{2}=0.4$ for vertical excitation only. Fig. 6(b) corresponds to $a_{1}=0.1, \quad a_{2}=0, \quad \Omega_{1}=4.05 \mathrm{~Hz}$ for horizontal excitation only. Fig. 6(c) corresponds to mutual action of horizontal and vertical excitations with abovementioned parameters. In this case the vibration process is unstable, both vertical and horizontal excitations are essential. The phenomenon of parametrical resonance can be observed. 


\section{Conclusion}

The method for estimation of liquid vibration in prismatic reservoir under action of periodic horizontal and vertical loads is developed. The nature of the behavior of the liquid in the reservoir is established depending on the frequency of the driving forces. The effects of instability are investigated. The effect of parametrical resonance at vertical excitation frequency equals to double own frequency of liquid vibrations is considered. The most dangerous liquid vibrations occur when the frequency of horizontal excitation coincides to own frequency of liquid vibrations, and the vertical excitation frequency equals to double value of own frequency.

\section{REFERENCES}

1. R.A. Ibrahim. Liquid Sloshing Dynamics. Cambridge University Press, New York, 2005.

2. Eselev E., Gnitko V., Strelnikova E. Intrinsic oscillations of high pressure vessels when interacting with a liquid. Institute of Mechanical Engineering problems. №1, 2006, pp.105-118. [in Russian]

3. Gnitko V., Naumenko V., Rozova L., Strelnikova E. "Multi-domain boundary element method for liquid sloshing analysis of tanks with baffles". Journal of Basic and Applied Research International, 17(1), pp. 75-87, 2016.

4. Gnitko, V., Naumemko, Y., Strelnikova E. "Low frequency sloshing analysis of cylindrical containers with flat and conical baffles", International Journal of Applied Mechanics and Engineering, 22 (4), pp.867-881, 2017.

5. Strelnikova E., Kriutchenko D., Gnitko V. "Liquid Vibrations in Cylindrical Quarter Tank Subjected to Harmonic, Impulse and Seismic Lateral Excitations", Journal of Mathematics and Statistical Science, V. 5, pp.31-41, 2019.

6. Strelnikova E., Gnitko V., Krutchenko D. , Naumemko Y. "Free and forced vibrations of liquid storage tanks with baffles" J. Modern Technology \& Engineering Vol.3, No.1, pp.15-52, 2018.

7. D.V.Krutchenko, E.A.Strelnikova, Y.S.Shuvalova. "Discrete singularities method in problems of seismic and impulse impacts on reservoirs". Bulletin of the Kharkiv National University Karazin series «Mathematical modeling. Information Technology. Automated Control Systems», 35(1),2017, pp. 31-37.

8. Nanjundan Parthasarathty, Hyunjong Kim, Yoon-Hwan Choi, Yeon-Won Lee. "A numerical study on sloshing impact loads in prismatic tanks under forced horizontal motion". Journal of the Korean Society of Marine Engineering, Vol. 41, No. 2 pp. 150 155, 2017.

9. Kim Y., "Numerical simulation of sloshing flows with impact load", Applied Ocean Research, vol. 23, no. 1, pp. 53-62, 2001.

10. Hyunjong Kim, Mohan Kumar Dey, Nobuyuki Oshima and Yeon Won Lee. "Numerical Study on Sloshing Characteristics with Reynolds Number Variation in a Rectangular Tank", Computation, 6, 53;pp. 2-11, 2018.

11. Koh, Hyun Moo, Jae Kwan Kim, and Jang - Ho Park. "Fluid-structure interaction analysis of 3 - D rectangular tanks by a variationally coupled BEM-FEM and comparison with test results". Earthquake engineering \& structural dynamics, 27.2 pp. 109-124, 1998.

12. Faraday, M., "On the forms and states of fluids on vibrating elastic surfaces", Philos. Trans. Roy. Soc. London, 52, pp. 319-340, 1831.

13. Kriutchenko D. "Computer simulation of forced fluid oscillations in a prismatic reservoir". Bulletin of the Kharkiv National University Karazin, pp. 42-47, 2018. [in Ukrainian]

\section{ЛІТЕРАТУРА}

1. R.A. Ibrahim. Liquid Sloshing Dynamics. Cambridge University Press, New York, 2005.

2. Еселева Е.В., Гнитько В.И., Стрельникова Е.А. Собственные колебания сосудов высокого давления при взаимодействии с жидкостью. Пробл. машиностроения. №1. 2006. С.105-118.

3. Gnitko V., Naumenko V., Rozova L., Strelnikova E. Multi-domain boundary element method for liquid sloshing analysis of tanks with baffles. Journal of Basic and Applied Research International. 17(1). 2016. pp. 75-87. 
4. Gnitko, V., Naumemko, Y., Strelnikova E. Low frequency sloshing analysis of cylindrical containers with flat and conical baffles. International Journal of Applied Mechanics and Engineering. 22 (4). 2017. pp.867-881.

5. Strelnikova E., Kriutchenko D., Gnitko V. Liquid Vibrations in Cylindrical Quarter Tank Subjected to Harmonic, Impulse and Seismic Lateral Excitations. Journal of Mathematics and Statistical Science. V. 5. 2019. pp.31-41.

6. Strelnikova E., Gnitko V., Krutchenko D. , Naumemko Y. Free and forced vibrations of liquid storage tanks with baffles J. Modern Technology \& Engineering Vol.3, No.1. 2018. pp.15-52.

7. D.V.Krutchenko, E.A.Strelnikova, Y.S.Shuvalova. Discrete singularities method in problems of seismic and impulse impacts on reservoirs. Вісник Харківського національного університету імені B.H. Каразіна, серія «Математичне моделювання. Інформаційні технології. Автоматизовані системи управління». 35(1). 2017. pp. 31-37.

8. Nanjundan Parthasarathty, Hyunjong Kim, Yoon-Hwan Choi, Yeon-Won Lee. A numerical study on sloshing impact loads in prismatic tanks under forced horizontal motion. Journal of the Korean Society of Marine Engineering. Vol. 41. No. 2. 2017. pp. 150 155.

9. Kim Y. Numerical simulation of sloshing flows with impact load. Applied Ocean Research. vol. 23. no. 1. 2001. pp. 53-62.

10. Hyunjong Kim, Mohan Kumar Dey, Nobuyuki Oshima and Yeon Won Lee. Numerical Study on Sloshing Characteristics with Reynolds Number Variation in a Rectangular Tank. Computation, 6. 53. 2018. pp. 2-11.

11. Koh, Hyun Moo, Jae Kwan Kim, and Jang - Ho Park. Fluid-structure interaction analysis of 3 - D rectangular tanks by a variationally coupled BEM-FEM and comparison with test results. Earthquake engineering \& structural dynamics. 27.2. 1998. pp. 109-124.

12. Faraday, M. On the forms and states of fluids on vibrating elastic surfaces. Philos. Trans. Roy. Soc. London. 52. 1831. pp. 319-340.

13. Крютченко Д. Комп'ютерне моделювання вимушених коливань рідини у призматичному резервуарі. Вісник Харківського наџіонального Університету імені В.Н. Каразіна. 2018. pр. 42-47.

Крютченко Денис Володимирович - аспірант;. Институт проблем машиностроения им. А.Н. Подгорного, вул. Пожсарського, 2/10, г. Харків, Україна, 61046; е-таіl: wollydenis@gmail.com; ORCID:0000-0002-6804-6991.

Крютченко Денис Владимирович - аспирант; Институт проблем машиностроения им. A.Н. Подгорного, ул. Пожарского, 2/10, г.Харьков, Украина, 61046; е-таil: wollydenis@gmail.com; ORCID:0000-0002-6804-6991.

Kriutchenko Denys - graduate student, A. Pidgorny Institute of mechanical engineering problems, vul. Pozharskogo, 2/10, Kharkiv, Ukraine, 61046; e-mail: wollydenis@gmail.com; ORCID: 0000-0002-6804-6991. 